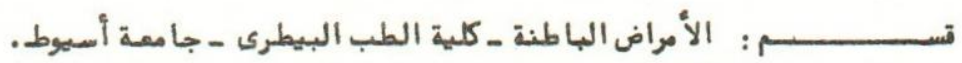

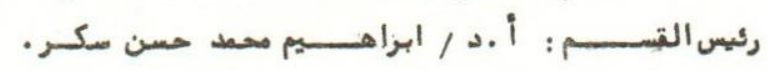

تقييم طريقة السمة السخية لتشخيه طفيل البابيزيا بيجمينا فى الصيوانات التى

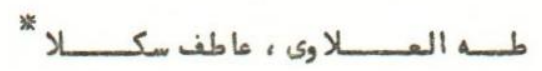

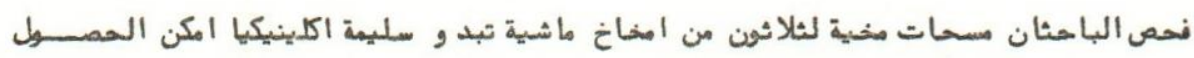

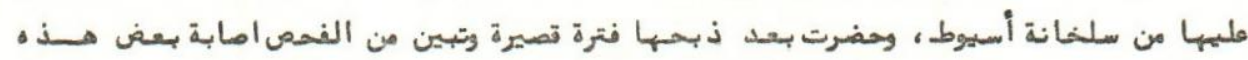

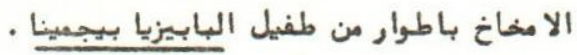

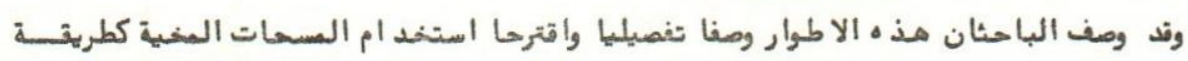

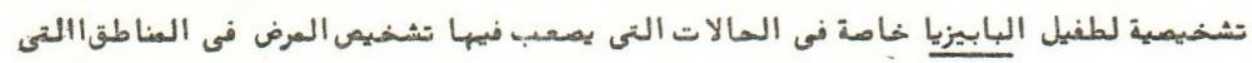
يستوطن فيها هذا الطفيل .

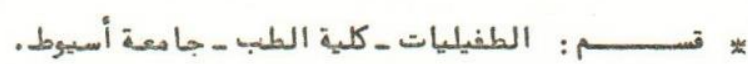

$$
\begin{aligned}
& \text { رئيسالقسم: أ .د / عماد كامل نافع }
\end{aligned}
$$


Depts. of Medicine 8 Infectious Diseases and Parasitology,

Faculty of Vet. Med., Assiut University,

Head of Dept. Prof. Dr. I. Sokker and Prof. Or. M. Fahny.

\title{
EVALUATION OF BRAIN SMEAR TECHNIQUE AS A METHOD FOR DIAGNOSIS OF BABESIA BIGEMINA (SMITH AND KILBRONE, 1893) IN CLINICALLY NORMAL CATTLE \\ (W1th Two Figures)
}

\author{
By \\ T. EL-ALLAWY and A.A. SAKLA
(Received at $3 / 1 / 1982$ )
}

\begin{abstract}
SUMMARY
Babesla bigemina parasites were encountered in the brain smears of clinically nomal cattle in Assiut Governosate. Two different forms were described and photomicrographed. This was the first report on this finding in Egypt, which might throw the light on the validity of using brain msear technique as dlagnostic method for concealed infection in clinically nomal cattle.
\end{abstract}

\section{INTRODUCTION}

Diagnosis of Babesia spp. In tissue smears has drawn the attention of few authors. ZLOTNIK (1953) claimed that Babesia bigemina was the causative parasite for cerebral piroplasmosis, and he described the brain smear forms. On the other hand, CALLOW (1963) based his investigations on brain smear technique for detection of $\underline{B}$. argentina in experimentally infected cattle as well as cattle fron enzootic area. The present study was carried out in order to throw further light on the importance of brain smear technique in diagnosis of babesiosis in clinically normal cattle in Assiut Governorate, upper Egypt.

\section{MATERIAL and METHODS}

Thirty brains of clinically normal cattle were obtained from Assiut abattoir shortly after slaughtering. A series of brain tissue smears were prepared from the grey matter of each case according to the technique adopted by CALLOW (1963). Smears were dried, fixed in methyle alchol and stained with Giemsa's stain. Carefull exawination of the stained smears were done under the oil immersion lens. Photomicrographs as well as measurements por the detected parasites were taken.

\section{RESULTS}

Examination of the stained brain smears revealed the presence of two different forms of B.bigemina infecting the red blood cells. These were small contracted anaplasma-11ke forms, up to one micron in diameter (Fig. 1 ). They usually occur as paired and occasionally as single parasite occupying the centre of the host erythrocytes. Vacuolated signet ring form up to 1.5 micron were also detected (Fig.2). They tend to lie singly in the centre of the host erythrocytes of the brain capillaries. Small number of the parasites in the smears were observed. Typical forms of B.bigemina could not be demonestrated.

\section{DISCUSSION}

In areas, for instance Assiut Governorate, where B. bigemina (tick fever) is known to be endemic, El-ALLAir (1973) and SAKLA (1975), 1t aust be stressed that the demonestration of the parasites in the peripheral blood for a spot diagnosis may require prolonged search. As a matter of fact, :LEVINE (1973) reported that cattle which have recovered from an attack of B.bigemina remain infected for life, and are premunized to reinfection. Premunltion is due to continuing low grade of infection, and premunized animals may show signs of disease under stress of one sort or another. The forementioned statment most probably representing an explanation for the evidence of

* Dept. of Parasitology, Faculty of Medicine, Assiut University. 
finding small number of the parasites in the brain smears of clinically normal cattle in the course of the present study. However, if we were asked wether these forms can reproduce the disease in another healthy cattle, it is difficult to state here a sharp answer as it needs another experimental study.

Few authors has drawn the attention of the confinement of the piroplasms in brain capillaries. ZLOTNIK (1953) described a cerebral form of prioplasmosis in cattle caused by B.bigemina. He stated that the parasitized red corpuscles blocked the brain capillarles which constitute an important cause of death. The dinding of ZLOTNIK (1953) was not inagreement with the present authros as well as CALLOw et al. (1963). Zoltnik animals acquired acute severe course, while those of the present work are clinically normal carriers. In addition, CALLON et al. (1963) believed that Zlotnik parasite was not B.bigemina. However, detection of the contracted forms of the organism in the red blood corpuscles of the brain capillaries in the present material accords with the finding of ZLOTNIK (1953). Furthermore, the present authors failed to find the typical forms of B.bigemina in their brain materlal, while Zlotnik (1953) reported the presence of these forms in one calf.

On the other hand, CALLOW (1963) reported the presence of B.argentina in the brain smears of 299 out of 458 cattle from enzootic areas, while he falled to detect B.bigemina in the same animals. However, he put in consideration the statment that brain smears were superior to other organs smear for the detection of babesiosis.

The forementioned data in the present study agreed with the finding of CALLOW et al. (1963) that B.bigemina was not incriminated as a cause of cerebral babesiosis in cattle, particularly by detection of small numbers of B.bigemina parasites in the brain smears of the clinically normal animals.

So far, the present work was the first to report the diagnosis of concealed infection in clinically normal carriers by using brain smear technique in Egytp. However, in cases of sudden death of cattle, babesiosis must be put in consideration and brain smears taken shortly after death is highly recommended.

\section{REFERENCES}

Callow, L.L. (1963): Babesia spp. in the brain of clinically normal cattle. Aust. Vet. J., 39, 25.

Callow, L.L. \& McGavin, M.D. (1963): Cerebral babesiosis due to Babesia argentina. Aust. Vet. J., $39,15$.

El-Allawy, T. (1973): Some studies on bovine piroplasmosis in Assiut. M.D.Vet. Thesis, Fac. Vet. Med., Assiut University, Egypt.

Levine, N.D. (1973): Protozoan parasites of domestic animals and man. 2nd. Ed., Burgess Publishing Company, Minneapolis, Minnesota.

Sakla, A.A. (1975): Studies on ticks in Assiut Governorate, with special references to their role in transmission of parasitic diseases. M.D.Vet. Thesis, Fac. Vet. Med., Assiut University, Egypt.

Zlotnik, I. (1953): Cerebral babesiosis in cattle. Vet. Rec., 65, 642. 


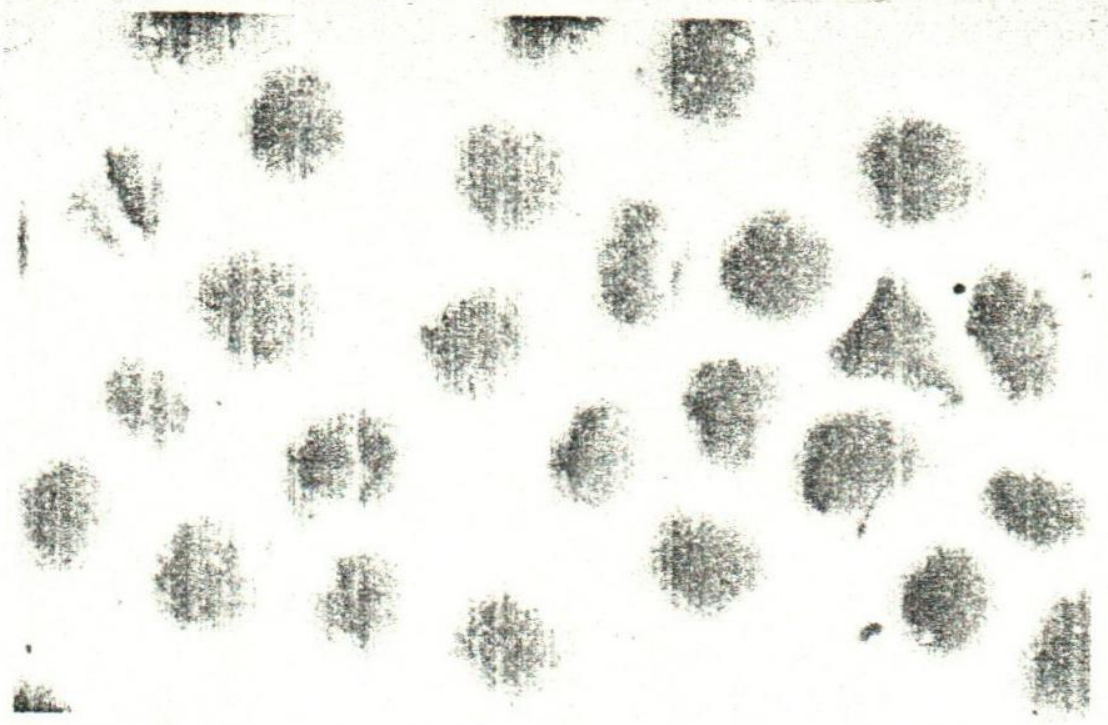

Fig. 1 Photomlcrograph showing single contracted

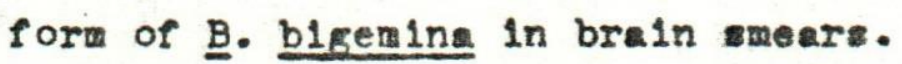

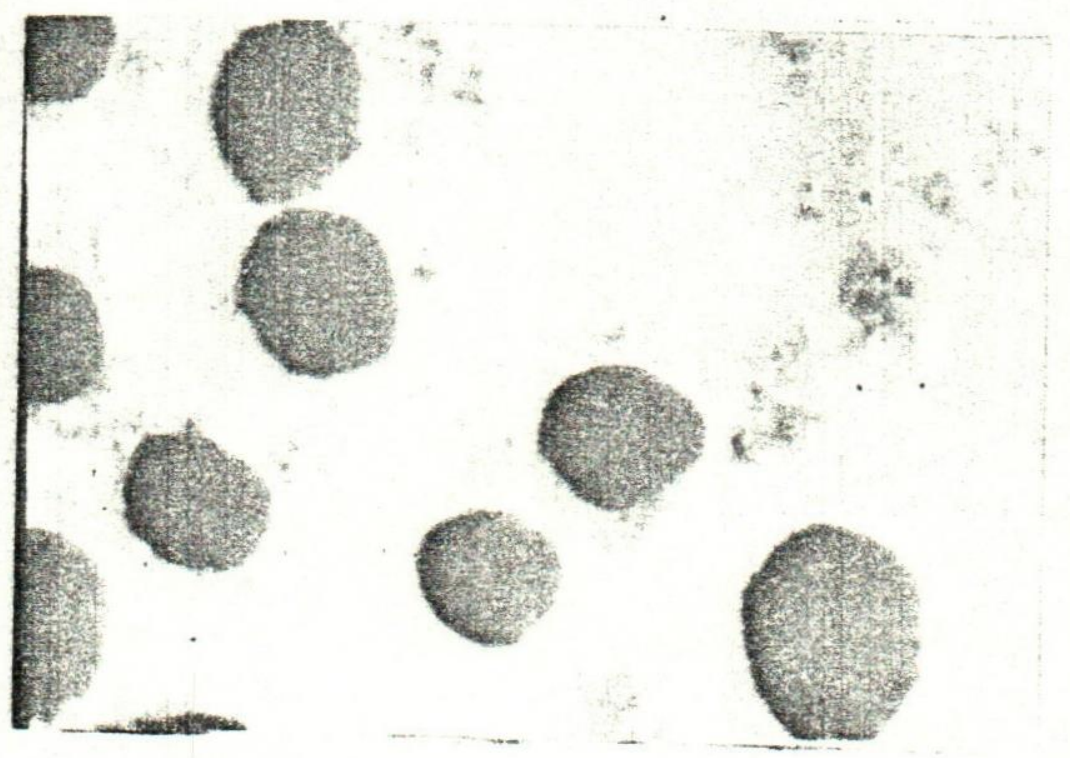

F1g. 2 Photomlcrograph shoving vacuolated ring form of $\underline{B}$. blgemina in brain sieear( Notice also a palred contracted form in the ame cell). 
